\title{
EDUKASI ASPEK KEAMANAN DAN PENGENDALIAN DATA GUNA MEMBANGUN LITERASI DIGITAL BAGI PELAKU UMKM
}

\author{
F.X. Kurniawan Tjakrawala ${ }^{1}$, Jamaludin Iskak ${ }^{2}$ \\ ${ }^{1,2}$ Program Studi Pendidikan Profesi Akuntan, Universitas Tarumanagara \\ ${ }^{1}$ Surel: kurniawant@fe.untar.ac.id
}

\begin{abstract}
Digital literacy is a real effort activity to communicate, relate, thinking, and other else by utilizing digital media. It's being admitted that building the digital literacy is not an instant thing. Moreover, for MSME preneurs who generally less educated and newbie in using internet technology, of course limiting their space and opportunities to adapt the digitization of business processes during the new normal because of the Covid-19 pandemic. The purpose of this community service activity is to provide counseling/training and practice to the activity's partners regarding aspects of data security and control in order to build adequate digital literacy for MSME preneurs, especially the culinary industry. The activity's partner is the owner of Restaurant "Seafood67 \& Soto Lamongan". The results of the survey and discussions with partners provide the identified problems that the owner of the restaurant has experienced hacking of the merchant application account in marketing their products; and often experience difficulties in recording financial transactions. The counseling/training activity took place for two days in April 2021 using the lecture, question-and-answer method and the practice of security supervision and transaction data control using an Android-based application. This activity also involves students from the PPAk of FEB UNTAR, who generally have experience from the world of work and are intended to be able to contribute in providing solutions to problems/facts in society. In addition, the participation of PPAk' students also had a positive impact on the accreditation of the study program. The activity resulted the fact that MSME preneurs became increasingly aware of the importance of digital literacy. The outcome of this community service activity is in the form of academic paper presented in the proceedings of scientific meetings.
\end{abstract}

Keywords: MSME, literacy, digital, android, culinary

\begin{abstract}
ABSTRAK
Literasi digital merupakan upaya nyata berkomunikasi; berelasi; berpikir, dan semua aktivitas dengan memanfaatkan media digital. Kita akui bersama bahwa membangun keliterasian digital bukanlah hal yang bersifat instan. Dan bagi pelaku UMKM yang umumnya berpendidikan rendah dan gagap menggunakan teknologi internet, tentunya membatasi ruang dan peluang mereka untuk beradaptasi terhadap digitalisasi proses bisnis pada masa normal baru sebagai akibat dari pandemi Covid-19. Tujuan dari kegiatan ini ini adalah mengadakan penyuluhan/pelatihan dan praktek kepada mitra mengenai aspek keamanan dan pengendalian data demi membangun literasi digital yang memadai bagi pelaku UMKM khususnya sektor industri kuliner. Mitra pada periode ini adalah Rumah Makan "Seafood67 \& Soto Lamongan”. Hasil survey maupun diskusi dengan mitra memberikan gambaran bahwa pemilik rumah makan tersebut pernah mengalami peretasan akun aplikasi merchant yang menjadi partner dalam pemasaran produknya; serta sering mengalami kendala aplikasi umtuk pencatatan transaksi keuangan. Kegiatan penyuluhan/pelatihan berlangsung selama dua hari pada bulan April 2021 dengan menggunakan metode ceramah, tanya-jawab dan juga praktek pengawasan keamanan dan pengendalian data transaksi menggunakan aplikasi berbasis android. Kegiatan PKM ini juga melibatkan mahasiswa dari Prodi PPAk FEB UNTAR, yang umumnya telah memiliki pengalaman dari dunia kerja dan dimaksudkan untuk mampu berkontribusi dalam memberikan solusi terhadap masalah riil/fakta di masyarakat. Selain itu keikutsertaan mahasiswa prodi PPAk juga berdampak positif terhadap akreditasi prodi PPAk FEB Untar. Hasil dari PKM ini dirasakan manfaatnya oleh mitra yang semakin sadar akan pentingnya literasi digital.PKM ini juga menghasilkan luaran berupa artikel ilmiah untuk keperluan publikasi pada prosiding pertemuan ilmiah.
\end{abstract}

Kata Kunci: UMKM, literasi, digital, android, kuliner,

\section{PENDAHULUAN}

Pandemi covid-19 berimbas pada lambatnya laju perekonomian nasional bahkan pada kuartal ketiga 2020 cenderung resesi. Namun demikian pemerintah senantiasa berupaya memulihkan kondisi perekonomian. Dana bansos telah beberapa kali disalurkan oleh pemerintah terhadap masyarakat yang terimbas pandemi. Akan tetapi hal tersebut belumlah efektif menambah daya 
beli masyarakat khususnya di kalangan bawah, guna belanja produk/jasa UMKM. Pandemi Covid-19 menggerus UMKM di berbagai wilayah Indonesia dari dua sisi, yaitu supply dan demand. Sebagai imbas terjerembabnya aspek distribusi dan arus kas gegara pandemi Corona, sekitar 50 persen UMKM cenderung bangkrut pada September 2020. Kebijakan social distancing dalam ujud PSBB/PTKM/PPKM di berbagai kotamadya/kabupaten/ provinsi, telah merontokkan daya tahan UMKM.

UMKM adalah salah satu penggerak perekonomian di Indonesia. UMKM memberikan kontribusi total Produk Domestik Bruto (PDB) sebesar 60,3\%, lapangan pekerjaan sebesar 99\%, dan menyerap tenaga kerja sebesar $97 \%$ di Indonesia. Di Indonesia, regulasi mengenai UMKM dengan merujuk pada UU No.20 Tahun 2008 yang mendefinisikan UMKM sebagai badan usaha dengan skala mikro; kecil; dan juga menengah yang kepemilikan dan pengelolaannya dilakukan oleh perorangan maupun kelompok dengan jumlah kekayaan dan pendapatan tertentu. BPS Indonesia membagi UMKM ke dalam dua kategori yaitu pertanian dan non-pertanian. Pelaku UMKM paling banyak dalam usaha non-pertanian terletak pada pedagang besar dan eceran, penyediaan akomodasi, sektor kuliner, serta industri pengolahan. UMKM merupakan sektor yang penting dan stratejik untuk pembangunan ekonomi nasional, tetapi memiliki kesulitan untuk naik kelas karena keterbatasan dalam masalah keuangan, manajemen, dan regulasi UMKM (Herwiyanti, Pinasti, \& Puspasari, 2020). Permasalahan UMKM baik internal maupun eksternal menyebabkan potensi UMKM belum dapat dioptimalkan seluruhnya. Tantangan utama bagi UMKM adalah penurunan daya beli sehingga menurunnya permintaan, fluktuasi tingkat suku bunga, maupun perebutan pasar UMKM karena adanya perilaku pemodal kuat yang ingin menguasai pasar (Wilantara \& Susilawati, 2016). Jika UMKM tidak memiliki keunggulan, maka pelaku UMKM tidak dapat bertahan untuk menjalankan usahanya karena tidak dapat memenangkan persaingan dan kurangnya penjualan (Ayodya, 2020). Era industri empat-nol memicu maraknya bisnis UMKM yang berpotensi untuk terus berkembang menjadi semakin besar. UU No. 20 tahun 2008 mensyaratkan bahwa UMKM harus berpijak pada wawasan lingkungan. Dengan demikian, pelaku UMKM secara bertanggungjawab dan berkelanjutan menjalankan bisnis yang peduli pada lingkungan hidup yang senantiasa terawat dan terlindungi. Hal ini tentu saja menjadi perhatian pemerintah baik pusat maupun daerah untuk memfasilitasi upaya pengembangan teknologi dan pelestarian lingkungan hidup oleh pelaku UMKM.

Peran serta dan eksistensi UMKM terbukti menjadi penyokong utama bagi ekonomi nasional. Data BPS, di Indonesia tahun 2018 menunjukkan bahwa UMKM mampu menyerap sekitar 116 juta pekerja. Dengan jumlah sekitar 64,2 juta yang tersebar di berbagai daerah yang mencakup 63,35 juta skala mikro, 783 ribu skala kecil serta 60.702 skala menengah. Demi membantu UMKM kembali bangkit, pemerintah merevitalisasi UMKM menuju proses digitalisasi. Konsumen kini telah banyak beralih ke belanja daring semasa pandemi dan kecenderungannya kelak pada saat memasuki keadaan normal baru. Namun hal tersebut belum banyak disadari oleh pelaku UMKM yang semata bersandar pada platform luring. Sehingga peluang menyediakan produk dan/atau jasa secara daring seperti layanan pariwisata, kuliner, kerajinan tangan, perkakas rumah tangga, kepada konsumenm malah luput dan tidak tersentuh. Hal ini tentunya mengancam kelangsungan UMKM untuk bertahan dalam lingungan bisnis yang berubah dengan cepat.

Sejatinya era industri 4.0 membuka peluang besar bagi UMKM untuk melakukan digitalisasi proses bisnisnya. Sejauh ini sudah banyak pelaku UMKM yang bermitra dengan pihak Gojek maupun Grab menjadi kanal baru yang mampu meningkatkan jangkauan pengiriman menambah pundi-pundi dari omzet penjualan. Selain hal tersebut, terbuka juga pilihan marketplace seperti tokopedia; bukalapak; shopee; olx dan sebagainya yang saat ini jumlahnya banyak dan relatif mudah untuk diterapkan menggunakan aplikasi pada ponsel. Tentunya melalui digitalisasi proses 


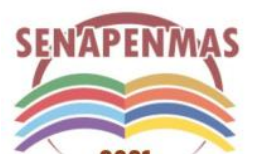

2021
Seminar Nasional Hasil Penelitian dan Pengabdian Kepada Masyarakat 2021

Pengembangan Ekonomi Bangsa Melalui Inovasi Digital Hasil Penelitian dan Pengabdian Kepada Masyarakat Jakarta, 21 Oktober 2021

bisnis diharapkan semakin banyak UMKM di Indonesia yang turut berkontribusi pada perekonomian bangsa ini.

Jones \& Hafner (2012) memaknai literasi digital sebagai kemampuan yang tidak sebatas teknis mengoperasikan komputer sebagai peralatan digital, namun juga mampu beradaptasi dengan segala aspek aktivitas sosial lainnya (termasuk mengelola relasi dan identitas sosial) yang dimediasi oleh teknologi digital. Literasi digital, merupakan upaya nyata berkomunikasi; berelasi; berpikir, dan semua aktivitas dengan memanfaatkan media digital. Dengan demikian, literasi digital, nerupakan pemahaman akan pengaruh penggunaan teknologi digital melalui media tertentu yang memberikan dampak terhadap beragam praktek literasi termasuk aktivitas baca tulis yang senantiasa berkembang (Seri Literasi Digital, 2018b; Gerakan Literasi Nasional, 2017). Kita akui bersama bahwa membangun keliterasian digital bukanlah hal yang bersifat instan. Dan bagi pelaku UMKM yang umumnya berpendidikan rendah dan gagap menggunakan teknologi internet, tentunya membatasi ruang dan peluang mereka untuk beradaptasi terhadap digitalisasi proses bisnis pada masa normal baru sebagai akibat dari pandemi Covid-19. Literasi digital membuka peluang lebih besar bagi pelaku UMKM untuk memasarkan produk dan/atau jasa dengan menggunakan teknologi digital.

Pada era modern ini, masyarakat semakin bergantung pada teknologi. Menurut hasil survey yang dilaksanakan oleh media Inggris We Are Social dan Hootsuite, melaporkan bahwa 46\% penduduk dunia alias 3.5 miliar manusia kini sudah melek dalam memakai media sosial. Bahkan prediksi tersebut mengatakan pengguna media sosial bakal bertumbuh hingga $60 \%$ dari total penduduk di dunia dalam beberapa tahun ke depan. Media sosial dapat dimanfaatkan oleh UMKM untuk melakukan berbagai aktivitas untuk menunjang perkembangannya (Ayodya, 2020). Media sosial dapat dimanfaatkan oleh UMKM untuk melakukan berbagai aktivitas untuk menunjang perkembangannya. Kemajuan era sekarang telah menunjukkan adanya perubahan gaya berbelanja pelanggan yang dulunya luring kini menjadi daring (Ayodya, 2020). Bahkan pemerintah juga sudah mengakui bahwa UMKM menjadi sektor yang begitu penting keberadaannya dalam membangun ekonomi nasional karena pertumbuhannya semakin hari semakin mengalami peningkatan (Herwiyanti, Pinasti, \& Puspasar, 2020).

Berbagai aturan pembatasan gerak dan aktivitas yang dirilis pemerintah pusat maupun daerah selama pandemi Covid-19 menyebabkan sebagian besar masyarakat melakukan aktivitas kerja; belajar; dan belanja berlangsung dari rumah dengan memanfaatkan internet. Di sisi lain, oleh karena seringnya penggunaan internet untuk kegiatan operasional formal maupun sekedar berselancar di dunia maya, ternyata disikapi secara salah oleh sejumlah oknum pelaku kejahatan siber yang mencoba mengambil kesempatan dalam kesempitan. Para penjahat siber ini seringkali memanfaatkan keluguan dan kenaifan dari para pengguna internet yang abai atau gagap memaknai potensi bahaya yang datang dari dunia siber. Beragam ujud serangan dalam lingkungan siber seringkali berupa aksi phising, lantas diikuti dengan serangan malware pengumpulan data, ransomware, penipuan melalui tautan daring. Google menampilkan data statistik bahwa sejak Januari 2020 dengan jumlah sekitar 149 ribu serangan phising yang memuat konten tipu-tipu bertema Covid-19, lalu meningkat hampir dua kali lipat menjadi sekitar 293 ribu pada Februari 2020, dan mencapai 522 ribu pada Maret 2020. Hal yang sejenis juga dilaporkan oleh Trend Micro yang menyatakan bahwa pada bulan Maret 2020, kasus Phising telah menembus hampir sejuta kasus melalui beraneka media seperti: berkas dokumen, web palsu, dan yang terbanyak melalui e-mail. Data yang dicuri tersebut lantas dipakai untuk tujuan jahat seperti membobol rekening bank dan juga aksi black-mail. Kondisinya mirip dengan aksi kejahatan siber sekitar tahun 2017 yaitu maraknya kasus virus komputer ransomware Wannacry. Kasus kejahatan siber selama pandemi juga berlangsung di Indonesia. Patrolisiber.id mengungkapkan bahwa sejak awal tahun sampai pertengahan Juni 2020 terlapor sejumlah 2.259 kasus kejahatan siber dan dari jumlah tersebut sebanyak 527 kasus dapat diselesaikan. Kejahatan 
siber banyak menyasar platform media sosial yaitu temuan 1874 kasus pada Whatsapp; diikuti 1781 pada tnstagram dan 854 kasus pada Facebook. Gambar 1 dan 2 menampilkan data statistik mengenai resiko serangan dam karakteristik kejahatan siber yang mengambil momen pandemi Covid-19.
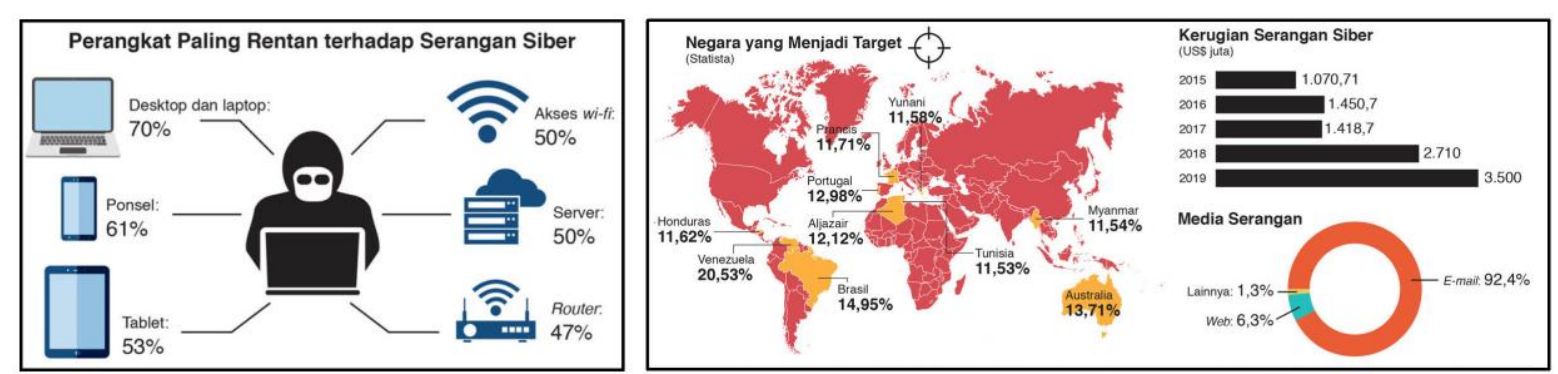

Gambar 1. Perangkat, Negara, \& Kerugian Terdampak Serangan Siber di Masa Pandemi Covid19

(Sumber: mediaindonesia.com, 2021)
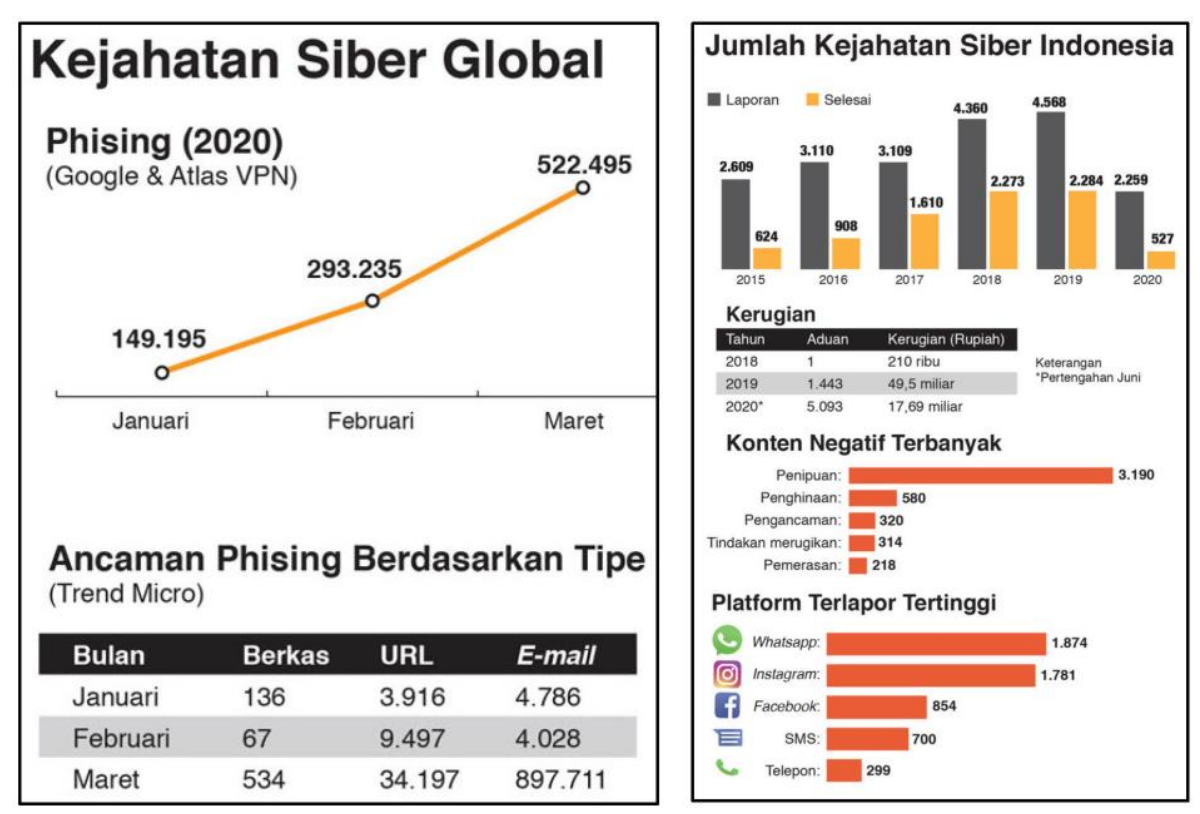

Gambar 2. Karakteristik Kejahatan Siber Global dan Indonesia di Masa Pandemi Covid-19

(Sumber: mediaindonesia.com, 2021)

IAI (2016) memaknai UMKM sebagai entitas skala mikro; kecil dan menengah yang tidak mengemban akuntabilitas secara signifikan terhadap publik, sebagaimana telah diatur dalam regulasi yang berlaku di Indonesia, setidaknya dalam kurun waktu dua tahun berturut-turut. Seperti telah dinyatakan oleh Hasan \& Gusnandi (2018) bahwa dalam perkembangannya UMKM di Indonesia menjumpai sejumlah kendala yang terkait dengan SDM, perizinan, promosi, maupun pembiayaan, dimana secara khusus mencakup: (a) tidak memahami praktek akuntansi atau pembukuan dikarenakan basis pendidikan yang tidak memadai; (b) pemilik usaha mungkin saja paham praktik akuntansi namun kurang disiplin dalam pelaksanaan aktivitas akuntansi atau pembukuan; (c) pemilik usaha belum cukup dana untuk merekrut akuntan profesional ataupun membeli software akuntansi guna melaksanakan praktik akuntansi; (d) kondisi yang memaksa kebutuhan akan informasi akuntansi yang muncul bila pemilik usaha dihadapkan pada kewajiban melampirkan laporan keuangan pada saat hendak mengajukan pmbiayaan melalui perbankan. Berkenaan dengan potensi pengembangan UMUM melalui 
lembaga pembiayaan, Diana (2018) menyatakan bahwa sebagian besar UMKM tidak menerapkan pembukuan untuk melaporkan aktivitas bisnisnya. Hal tersebut berdampak pada sulitnya lembaga pembiayaan untuk menilai kinerja UMKM yang mencoba mengajukan pinjaman untuk pengembagan usaha. Kendati terdapat UMKM yang melakukan pembukuan, namun tatabuku UMUM cenderung sederhana dan bahkan tidak mengikuti standar.

Keberhasilan usaha bisnis-baik skala UMKM maupun besar-tidak terlepas dari peran informasi akuntansi. Para manajer perusahaan berpijak pada informasi akuntansi guna dapat mengontrol biaya, melakukan penghitungan dan penetapan harga jual, serta menginvestasikan sumber daya perusahaan ke bidang usaha yang lebih produktif (Hasan \& Gusnandi, 2018). Pelaku bisnis tentunya memerlukan informasi akuntansi dalam pengambilan keputusan yang berkenaan dengan: (a) siklus pengeluaran pada saat melakukan aktivitas pembelian bahan baku untuk kegiatan produksi serta pada saat mengganti aset tetap untuk kegiatan produksi; (b) siklus pendapatan yang berkenaan dengan harga jual; (c) siklus pendanaan bilamana mengajukan pinjaman kepada lembaga keuangan bank ataupun non-bank guna pengembangan usaha; (d) siklus penggajian pada saat akan melakukan penggajian maupun pengembangan SDM; (e) siklus produksi pada saat akan menghitung kos dalam menghasilkan produk. Dengan adanya informasi akuntansi tentu akan mempermudah dalam menyusun berbagai laporan sesuai dengan kebutuhan pengguna. Hal ini tentu saja akan berimbas pada pihak-pihak yang berkepentingan dalam menilai seberapa baik tata kelola usahan yang dilakukan dalam memanfaatkan ketersediaa sumberdaya yang terbatas (Romney \& Steinbart, 2018; Gelinas, Dull, Wheeler, \& Hill, 2018; Hasan \& Gusnandi, 2018; Ediraras, 2010).

PKM periode I tahun 2021 masih melibatkan mitra yang sama dengan periode lalu yaitu: Rumah Makan "Seafood67 \& Soto Lamongan" yang berlokasi di Jl. Boulevard No.12R, Ruko Taman Palma Blok C1, kecamatan Panongan, kabupaten Tangerang-Banten, 15710. Lokasi tersebut berjarak sekitar $36 \mathrm{KM}$ dari Universitas Tarumanagara Kampus 1, dengan waktu tempuh normal sekitar 40 hingga 60 menit bila menggunakan kendaraan pribadi atau taksi online melewati jalur tol Merak-Jakarta atau jalur tol Jakarta-Tangerang. Rumah Makan "Seafood67 \& Soto Lamongan" dimiliki oleh Bapak Suwadji. Bapak Suwadji sudah menggeluti usaha kuliner berupa warung tenda pecel lele sejak tahun 1998 dengan berlokasi di daerah Ciledug, Tangerang. Kemudian sejak tahun 2002, beliau pindah lokasi ke kompleks perumahan di Kabupaten Tangerang, dan masih tetap berupa warung tenda. Pada awal perkembangan usaha kuliner tersebut, bapak Suwadji menggunakan label "Seafood67" untuk warung tenda yang dikelolanya bersama sang istri. Selain pecel lele, beliau juga menjualan makanan hasil laut lainnya seperti cumi, kerang, udang, kepiting, dan ikan laut. Beliau juga melengkapi menu usaha kuliner seafoodnya dengan nasi uduk, serta daging bebek dan ayam yang diolah dengan dibakar atau digoreng. Sambal buatan bapak Suwadji ternyata sangat diminati oleh para pelangggannya sampai sekarang.

Pada tahun 2015, bapak Suwadji mencoba peruntungan usaha kulinernya dan tidak lagi menggunakan warung tenda melainkan bangunan permanen dengan mengontrak ruko di kawasan perumahan, yaitu Ruko Taman Palma blok C1 No. 12R. Selain itu, beliau juga memberanikan diri membuka cabang dengan berlokasi di daerah Curug, Tangerang. Usaha semakin berkembang dengan total karyawan sebanyak 15 orang dengan penempatan sembilan orang di daerah Panongan dan enam orang di daerah Curug. Pada tahun 2017, Bapak Suwadji menambah menu tetap di rumah makannya dengan soto lamongan. Sehingga label rumah makannya menjadi "Seafood67 \& Soto Lamongan". Bapak Suwadji menyatakan kepada tim bahwa rumah makannya setiap hari beroperasi mulai pukul 10 pagi hingga pukul 1.30 dini hari dengan pembagian dua shift kerja bagi karyawannya. Rumah Makan "Seafood67 \& Soto Lamongan" juga telah bermitra dengan grabfood dan gofood. Hal ini dilakukan oleh bapak Suwadji untuk memperluas pangsa pasar usaha kulinernya. Dengan demikian, bapak Siwadji 
tidak hanya melayani konsumen yang dine-in tetapi juga terhadap konsumen yang melakukan pesan antar secara online. Pada kondisi ini dapat dipahami oleh tim bahwa bapak Suwadji relatif peka terhadap tuntutan zaman yang terus berubah, sehingga usaha kulinernya pun merambah kepada layanan digital.

Rumah Makan "Seafood67 \& Soto Lamongan” telah memanfaatkan kecanggihan teknologi. Bapak Suwadji dalam wawancara dengan tim menyatakan bahwa beliau khawatirt dengan maraknya aksi peretasan akun melalui media aplikasi yang ada di ponsel. Bahkan yang pernah dialami sendiri oleh beliau dimana akun gojek dan grab miliknya diretas. Selain itu, terkait dengan pemakaian aplikasi "BukuWarung", Pak Suwajie mengakui beberapa kali mengalami kondisi gagal login dan keliru angka dalam laporan yang ditampilkan, Oleh karena sebelumnya tim telah memberikan bantuan pelatihan/tutorial mengenai pemanfaatan aplikasi "BukuWarung" sebagai sistem pencatatan dan juga pelaporan transaksi usaha mitra. Aplikasi ini tergolong sederhana dan dapat dioperasikan melalui ponsel android setelah mengunduh dari playstore dan kemudian menginstal aplikasi tersebut. Pada akhirnya tim memutuskan untuk menggunakan media aplikasi bernama "BukuWarung" yang memang diklaim oleh developernya sebagai aplikasi keuangan UMKM berbasis android terbaik. Tim telah sepakat dengan bapak Suwadji selaku mitra PKM bahwa PKM periode I 2021 ini akan fokus pada topik aspek keamanan dan pengendalian data transaksi demi membangun literasi digital bagi mitra PKM yaitu rumah makan "Seafood67 \& Soto Lamongan". PKM periode 1 tahun 2021 ini mengikutsertakan komponen mahasiswa dari prodi PPAk. Umumnya mahasiswa prodi PPAk telah bekerja di perusahaan selama beberapa tahun yang tentunya akan berdampak pada sudut pandang dan kemampuan analsis terhadap masalah riil dalam fakta kehidupan sosial masyarakat. Selain itu keikutsertaan mahasiswa prodi PPAk juga berdampak positif terhadap borang prodi PPAk FEB Untar.

\section{METODE PELAKSANAAN PKM}

Kegiatan PKM periode 1 (satu) tahun 2021 terselenggara dengan menggunakan dana hibah internal LPPM UNTAR berdasarkan penugasan dari Ketua LPPM Untar yaitu surat tugas No.245-Int-KLPPM/UNTAR/III/2021 serta No.251-Int-KLPPM/UNTAR/III/2021. Kegiatan ini merupakan kegiatan ilmiah dengan mekanisme sistematis yang mencakup tahap perencanaan, pelaksanaan, serta tahap pelaporan hasil. Dengan demikian, kelancaran pada setiap tahapan akan sangat menentukan kelanjutan dari tahapan berikutnya. Koordinasi antar personil tim pengusul sangat dibutuhkan demi keberhasilan kegiatan PKM ini. Kegiatan ini berlangsung selama 2 (dua) hari. Partisipasi mitra berlangsung dengan menginisiasi undangan resmi kepada tim untuk menyelenggarakan suatu event berupa aktivitas penyuluhan sekaligus pelatihan kepada pihak mitra dengan berlokasi pada tempat usaha mitra. Metode yang dipakai dalam PKM ini adalah metode ceramah, tanya-jawab dan praktek materi modul belajar. Solusi yang ditawarkan kepada mitra berupa penyuluhan yang berkaitan dengan aspek keamanan dan pengendalian data digital berkenaan dengan penggunaan aplikasi "BukuWarung" untuk keperluan pencatatan dan pelaporan transaksi keuangan UMKM. Materi disajikan kepada mitra, baik dalam bentuk handout maupun hardcopy modul tutorial.

Kegiatan abdimas yang telah dilakukan sejauh ini adalah kegiatan yang sesuai dengan spesialisasi keahlian masing-masing personil tim yang terdiri dari dua orang dosen tetap pada program studi PPAk FEB UNTAR yang meliputi satu orang ketua dan satu orang anggota. Tim ini juga melibatkan satu orang mahasiswa dari prodi PPAk. Tujuan PKM ini adalah memberikan solusi yang optimal bagi permasalahan yang dialami pemilik usaha rumah makan (bapak Suwadji). Beliau mengikutsertakan semua karyawan dari dua lokasi usahanya yaitu wilayah pusat usaha di wilayah Panongan dan cabang di wilayah Curug. Mitra PKM yang sekaligus 
merupakan pemilik usaha menghendaki agar semua karyawannya baik yang bagian masak, bagian administrasi, maupun bagian umum dapat menggunakan aplikasi berbasis android. Mitra PKM berkeinginan membekali pengetahuan pembukuan kepada semua karyawannya, karena aplikasi "BukuWarung" memiliki sejumlah fitur yang juga dapat digunakan untuk pembukuan rumah tangga sehingga dapat diterapkan untuk keperluan sehari-hari.

\section{HASIL DAN PEMBAHASAN}

Mitra PKM ini adalah pemilik usaha Rumah Makan "Seafood67 \& Soto Lamongan" yang juga mengikutsertakan +/- 15 karyawannya baik dari bagian operasional maupun administrasi dari dua lokasi usaha yaitu pusat dan cabang. Kegiatan PKM berlangsung selama dua hari kerja yaitu pada hari Jum'at dan Sabtu tanggal 2 dan 3 April 2021 pada pukul 9.00 s/d 11.00 WIB. Oleh karena terdapat kendala teknis dari pihak mitra, maka kegiatan penyuluhan dan pelatihan tidak dapat berlangsung secara daring menggunakan media zoom. Pada akhirnya tim PKM dan mitra dapat melangsungkan kegiatan PKM secara luring dan tentu saja dengan menerapkan protokol kesehatan yang memadai.

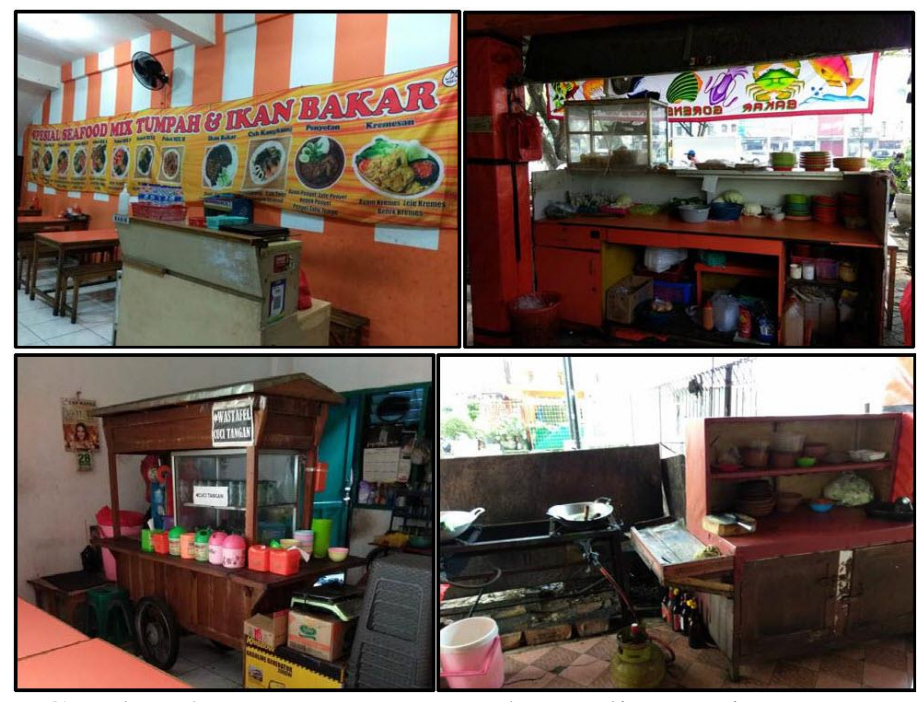

Gambar 3. Foto Layout Usaha Kuliner Mitra PKM

(Sumber: dokumentasi tim, 2021)

Aktivitas PKM dilakukan dalam satu rangkaian tahapan yang terdomumentasikan dalam logbook sebagaimana ditampilkan pada Tabel 1. Hal lain yang terdokumentasi pada saat survey awal dilakukan di lokasi mitra, tim berkesempatan mengabadikan sejumlah foto layout rumah makan tersebut pada pagi hari sebelum pukul 10 ketika bapak Suwadji dan para karyawannya masih mempersiapkan semua perlengkapan usahanya. Foto-foto yang dimaksud dapat diamati pada Gambar 3. Bapak Suwadji terkesan amat menjaga kebersihan dan kerapihan area usahanya demi membuat para pelanggannya merasa nyaman pada saat menikmati kuliner di rumah makan tersebut. 
Tabel 1. Tabulasi Kegiatan Tim PKM Periode-1 Tahun 2021

\begin{tabular}{|c|c|c|}
\hline $\begin{array}{c}\text { Tahapan } \\
\text { Pelaksanaan PKM }\end{array}$ & Periode Waktu & Kegiatan \\
\hline Tahap Perencanaan & $\begin{array}{c}\text { Jan-2021 } \\
\text { S/d } \\
\text { Mar-2021 }\end{array}$ & $\begin{array}{l}\text { Pertemuan informal dengan mitra; survey pendahuluan; } \\
\text { identifikasi masalah; lakukan studi literatur yang } \\
\text { relevan } \\
\text { Menyusun proposal PKM periode-1 tahun } 2021 \\
\text { Mengajukan proposal kepada LPPM UNTAR (hibah } \\
\text { internal UNTAR) periode } 1 \text { tahun } 2021\end{array}$ \\
\hline Tahap Pelaksanaan & $\begin{array}{c}\text { 2-Apr-2021 } \\
\text { s/d } \\
\text { 3-Apr-2021 }\end{array}$ & $\begin{array}{l}\text { Pembuatan modul belajar yang relevan dengan } \\
\text { permasalahan yang dialami oleh mitra PKM yaitu } \\
\text { Edukasi Aspek Keamanan \& Pengendalian Data Guna } \\
\text { Membangun Literasi Digital } \\
\text { *elaksanaan PKM di lokasi mitra meliputi ceramah, } \\
\text { tanya-jawab, praktek aspek keamanan dan pengendalian } \\
\text { data digital } \\
\text { *enyusunan luaran wajib berupa makalah untuk } \\
\text { publikasi tahun } 2021 \\
\text { Pembuatan luaran tambahan berupa makalah populer } \\
\text { pada media "Pintar" }\end{array}$ \\
\hline Tahap Pelaporan & $\begin{array}{c}\text { Apr-2021 } \\
\text { s/d } \\
\text { Jul-2021 }\end{array}$ & $\begin{array}{l}\text { Persiapan untuk kegiatan monev } \\
\text { Penyusunan laporan akhir dan laporan keuangan }\end{array}$ \\
\hline
\end{tabular}

Gambar 4 menyajikan tampilan utama dari aplikasi berbasis android bernama "BukuWarung". Tim meminta pihak mitra untuk menginput data transaksi rumah makan secara riil. Faktor kepraktisan dari aplikasi "BukuWarung" turut menjadi penentu kelancaran kegiatan PKM ini. Oleh karena peserta umumnya menggunakan ponsel android dalam kegiatan komunikasi seharihari, menjadikan praktik penggunaan aplikasi "BukuWarung" relatif tidak rumit bagi peserta. Namun demikian, fokus tim PKM kali ini memberikan penekanan pada aspek pengendalian data transaksi.
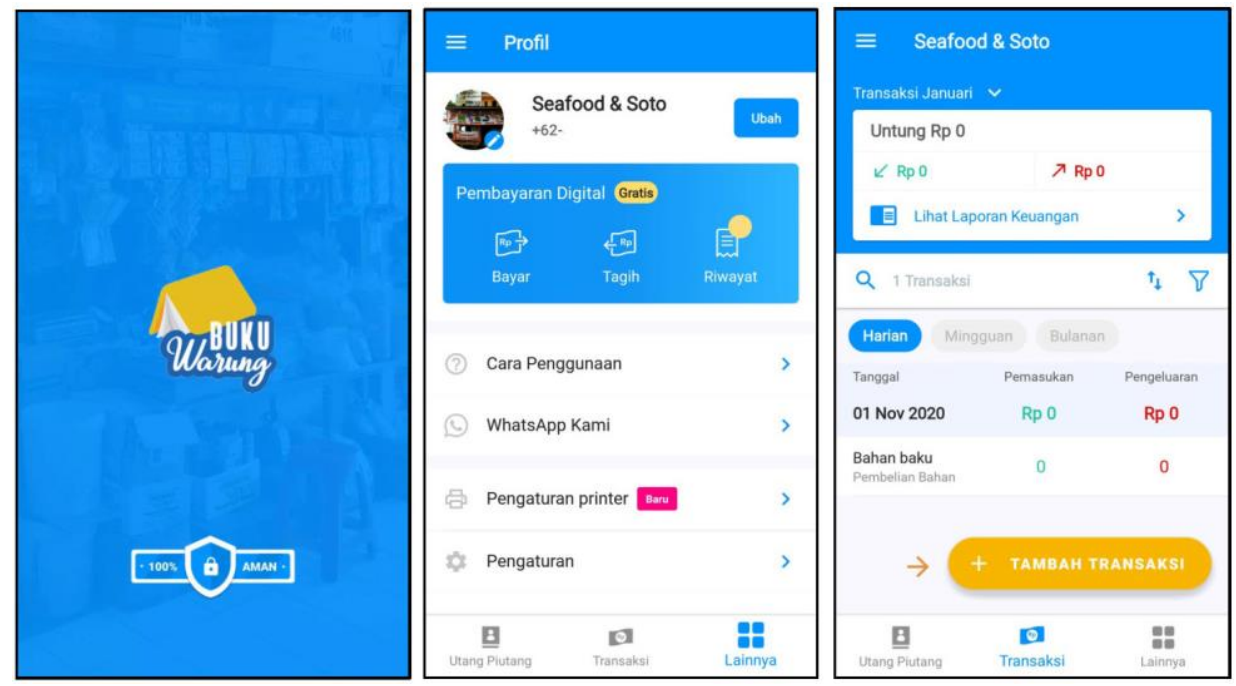

Gambar 4. Tampilan Utama Aplikasi Android BukuWarung

(Sumber: Screenshot Aplikasi BukuWarung, 2021)

Para peserta umumnya memberikan respon positif dengan serius menyimak paparan materi modul dan aktif bertanya pada saat berlangsung praktik input data dan mengenal aspek otentikasi dan validasi data yang berlangsung dengan menggunakan aplikasi "BukuWarung" maupun 
aplikasi merchant partner dari Rumah Makan "Seafood67 \& Soto Lamongan". Permasalahan terkait kekeliruan laporan keuangan UMKM teratasi dengan paparan bahwa input data pada aplikasi memang harus benar dan seksama. Karena bila penginputan keliru maka hasilnya juga akan keliru. Hal tersebut merupakan bagian dari kontrol input. Kontrol input mencakup desain formulir, penyimpanan file, otorisasi dan segregasi, dan kontrol entri data.

Aspek keamanan transaksi digital dijabarkan oleh tim dengan menggunakan Rerangka Layanan Kepercayaan yang mengintegrasikan lima prinsip kontrol lingkungan teknologi informasi guna berkontribusi pada keandalan sistem. Rerangka Layanan Kepercayaan mencakup: a) Keamanan, dimana berlangsung kendali dan pembatasan akses akses terhadap sistem maupun data hanya bagi pengguna yang terotorisasi; b) Kerahasiaan, yang mana kontrol ini melindungi informasi perusahaan yang bersifat sensitif agar tidak terungkap secara tidak tepat dan sah: c) Privasi, berhubungan dengan pengumpulan, pemeliharaan, dan pengungkapan semua data individual menyangkut karyawan, pelanggan, pemasok sesuai dengan kebijakan internal dan regulasi eksternal; d) Integritas Pemrosesan, kontrol berupa otorisasi yang memadai dengan memproses data secara lengkap, akurat, tepat waktu: e) Availability, guna memastikan bahwa aktivitas operasional dan kewajiban kontraktual senantiasa disokong oleh ketersediaan data dari sistem informasi.

Para peserta PKM juga diberi pemahaman terkait dengan resiko kejahatan siber yang umum terjadi. Phising, yaitu Kegiatan yang dilakukan melalui e-mail dengan maksud menggali datadata vital menyangkut individu tertentu (contoh: username, password); Malicious domains, yaitu pelaku kejahatan siber yang memunculkan situs-situs jebakan untuk melaksanakan aktivitas phishing, spamming, atau menyebarkan malware; Malware merupakan sebutan berbagai software berbahaya (termasuk ransomware) yang dapat meretas dan membajak sistem perangkat dan juga mencuri data; Rekayasa sosial, yaitu kejahatan siber dengan mengakses data pribadi yang kemudian digunakan untuk membajak akun dan meniru/memalsukan identitas; Denial of service, yaitu kejahatan siber yang dilakukan dengan secara intensif merongrong situs tertentu dengan request secara masif kepada server dan akibatnya server tidak mampu menampung request baru. Hal ini bertujuan untuk menutup akses kepada pengguna terhadap situs tertentu (Seri Literasi Digital, 2018a).

Bapak suwadji bahkan antusias sekali pada saat praktik dan meminta kepada semua karyawannya agar mulai membiasakan petingnya kesadaran pada aspek keamanan dan pengendalian tatkala menggunakan aplikasi "BWG" dalam pencatatan transaksi keuangan baik di lokasi kerja maupun untuk keperluan rumah tangga saja. Hasil dari kegiatan PKM selama dua hari ini memberikan manfaat nyata yaitu mitra PKM mengetahui betapa pentingnya literasi digital pada saat bersentuhan dengan dunia siber yang rawan pada faktor keamanan dan perlu melakukan kontrol dengan seksama. Kegiatan ini menghasilkan luaran berupa draft publikasi untuk event SENAPENMAS 2021 dan juga luaran tambahan yaitu draft artikel populer untuk publikasi di media online PINTAR.

\section{KESIMPULAN}

Aktivitas tim abdimas/PKM periode pertama tahun 2021 berupa penyuluhan dan pelatihan di Rumah Makan "Seafood67 \& Soto Lamongan" dalam rangka memberi edukasi tentang aspek keamanan dan pengendalian data guna meningkatkan literasi digital. Kegiatan PKM ini berlangsung selama dua hari (Jum'at dan Sabtu) tanggal 2 \& 3 April 2021). Metode pelaksanaan PKM meliputi aktivitas ceramah; tanya-jawab, dan praktik oleh mitra dengan dipandu oleh tim. Kendati aplikasi "BukuWarung" mempermudah pengguna dalam pencatatan dan pelaporan namun berpotensi memunculkan masalah keamanan jika pengguna abai atau tidak paham dengan upaya pengendalian yang memadai atas transaksi-transaksi digital. Oleh karena Rumah Makan "Seafood67 \& Soto Lamongan" juga bermitra dengan pihak Grab dan Gojek untuk penjualan 
produkya, maka mitra PKM semakin tahu tentang pentingnya keamanan dan pengendalian data digital yang rentan dari resiko kejahatan siber. Mitra PKM merasakan manfaat dari aktivitas PKM dan peserta PKM yang semuanya merupakan karyawan di Rumah Makan "Seafood67 \& Soto Lamongan". Antusiasme dari para peserta PKM yang mengajukan pertanyaan seputar issu keamanan data digital menunjukkan bahwa para peserta mendapatkan manfaat dari aktivitas PKM periode 1 tahun 2021.

\section{Ucapan Terima Kasih (Acknowledgement)}

Kegiatan PKM pada periode pertama tahun 2021 ini terselenggara dengan dukungan dari berbagai pihak. Penulis secara khusus berterimakasih kepada Ketua LPPM Untar, bapak Ir. Jap Tji Beng, Ph.D; Manajer LPPM bidang PKM, ibu Dr. Ir. Endah Setyaningsih, M.T.; bapak Suwadji pemilik usaha Rumah Makan "Seafood67 \& Soto Lamongan" yang masih tetap berkenan menjadi mitra kegiatan abdimas ini.

\section{REFERENSI}

Ayodya, W. (2020). UMKM 4.0: strategi umkm memasuki era digital. Jakarta: Elex Media Komputindo.

Diana, N. (2018). Financial accounting standards for micro, small \& medium entities (sak emkm) implementation and factors that affect it. Jurnal ilmiah bidang akuntansi dan manajemen, 15(2): 50 -59.

Ediraras, D.T. (2010). Akuntansi dan kinerja ukm. Jurnal ilmiah ekonomi bisnis. 15(2): 152-158.

Fajar, M. (2015). UMKM dan globalisasi ekonomi. Yogjakarta: LP3EM UMY.

Gelinas, U.J., Dull, R.B.. Wheeler, P.R., \& Hill, M.C. (2018). Accounting information systems, $11^{\text {th }}$ edition. Boston: Cengage Learning.

Gerakan Literasi Nasional. (2017). Materi pendukung literasi digital. Jakarta: Kemendikbud.

Hasan, A. \& Gusnardi. (2018). Prospek implementasi standar akuntansi: entitas mikro, kecil dan menengah berbasis kualitas laporan keuangan yang berlaku efektif per 1 januari 2018. Bandung: The Sadari Institute.

Hall, J.A. (2019). Accounting information system. 10th edition. Cengage.

Herwiyanti, E., Pinasti, M., \& Puspasari, N. (2020). Riset umkm: pendekatan multiperspektif. Yogyakarta: Deepublish

Ikatan Akuntan Indonesia. (2016). Standar akuntansi keuangan entitas mikro kecil dan menengah. Jakarta: DSAK-IAI.

Jones, R.H. \& Hafner, C.A. (2012). Understanding digital literacies: a practical introduction. Routledge: Taylor \& Francis Group. London.

Romney, M.B. \& Steinbart, P.J. (2018). Accounting information system, $14^{\text {th }}$ global edition. Edinburgh Gate, Harlow: Pearson Education.

Seri Literasi Digital. (2018a). Keamanan siber untuk e-commerce. Jakarta: Kominfo \& ICT. . (2018b). Pengantar tatakelola internet. (edisi revisi). Jakarta: Kominfo \& ICT.

Wilantara, R. F., \& Susilawati. (2016). Strategi dan kebijakan pengembangan umkm: upaya meningkatkan daya saing umkm nasional di era mea. Bandung: Refika Aditama. 